\title{
Identification and characterization of endophytic bacteria isolated from in vitro cultures of peach and pear rootstocks
}

\author{
Fakhra Liaqat $^{1} \cdot$ Rengin Eltem $^{2}$
}

Received: 17 February 2016/Accepted: 25 May 2016/Published online: 3 June 2016

(c) The Author(s) 2016. This article is published with open access at Springerlink.com

\begin{abstract}
Endophytes are microorganisms which live symbiotically with almost all varieties of plant and in turn helping the plant in a number of ways. Instead of satisfactory surface sterilization approaches, repeatedly occurring bacterial growth on in vitro rootstock cultures of peach and pear was identified and isolated as endophytic bacteria in our present study. Five different isolates from peach rootstocks were molecularly identified by $16 \mathrm{~S}$ rRNA gene sequencing as Brevundimonas diminuta, Leifsonia shinshuensis, Sphingomonas parapaucimobilis Brevundimonas vesicularis, Agrobacterium tumefaciens while two endophytic isolates of pear were identified as Pseudoxanthomonas mexicana, and Stenotrophomonas rhizophilia. Identified endophytes were also screened for their potential of plant growth promotion according to indoleacetic acid (IAA) production, nitrogen fixation, solubilization of phosphate and production of siderophore. All seven endophytic isolates have shown positive results for IAA, nitrogen fixation and phosphate solubilization tests. However, two out of seven isolates showed positive results for siderophore production. On the basis of these growth promoting competences, isolated endophytes can be presumed to have significant influence on the growth of host plants. Future studies required to determine the antimicrobial susceptibility profile and potential application of these isolates in biological control, microbial biofertilizers and degradative enzyme production.
\end{abstract}

Fakhra Liaqat

fakhra243@gmail.com

1 Department of Biotechnology, Graduate School of Natural and Applied Sciences, Ege University, İzmir, Turkey

2 Department of Bioengineering, Ege University Faculty of Engineering, 35100 Bornova, Izmir, Turkey
Keywords Endophyte - Peach rootstock - Pear rootstock · Plant growth promoting properties $\cdot 16 \mathrm{~S}$ rRNA gene sequencing

\section{Introduction}

Endophytes are bacteria or fungus which colonize healthy plant tissue, residing within a plant cell or between plant tissues with no apparent symptoms of disease (Nair and Padmavathy 2014). These endophytic microorganisms can spend their life cycle or a part of it while invading living tissue of the host plant deprived of producing any harm, with sometimes causing unapparent and asymptomatic infections (Kumala and Siswanto 2007). Endophytic bacteria frequently reside most of the plant and not a single plant species studied till date have been found free of endophytic bacteria (Nair and Padmavathy 2014). It is worth mentioning that, a huge number of existing plant species are host to more than one types of endophytes. Endophytic biology of all those plants is not fully studied. Therefore, it is a considerable opportunity to discover novel and valuable microorganisms among these plants (Muzzamal et al. 2011). While living symbiotically with the plants, these bacteria are known to stimulate plant growth by different ways including the production of phytohormones, solubilization of inorganic minerals like phosphate, fixation of atmospheric nitrogen and sequestration of iron. Additionally, they sometimes offer protection against pathogenic microorganisms and augmentation of ecological constraints such as drought, salinity and heavy metals (Khalifa et al. 2015). On the other hand, the presence of bacteria growth in in vitro plant tissue culture is generally declared as contaminants, which must be prohibited and eradicated (George et al. 2008; Abreu-

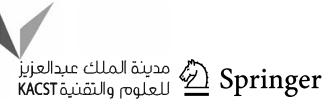


Tarazi et al. 2010). Detecting the presence of endophytes in in vitro plant tissue culture and micropropagated plants is not extensively studied spot. Rarely, a few studies reported the manifestation of endophyte in in vitro plant tissue cultures (Almeida et al. 2009; Dias et al. 2009; AbreuTarazi et al. 2010; Moraes et al. 2012). The presence of valuable endophytic bacteria in plant tissue cultures and in their micropropagations may be more frequent than that reported (Abreu-Tarazi et al. 2010). In vitro plant tissue culture may offer a useful system and source to recover beneficial microorganisms resides within specific organs (Moraes et al. 2012). For a successful recovery of endophytes from plant tissues, it is foremost important to discriminate and eliminate any surface contaminants of plants, because endophytes purely reside inside the plant. In in vitro explant cultivation, plant materials are generally extensively surface sterilized, but inner flora of plant tissues cannot be avoided by surface sterilization approaches. The present study was, therefore, undertaken to identify and characterize endophytic bacteria appeared in in vitro explant cultures of GF677 (Prunus amygdalus $\times$ P. persica) peach rootstocks and OHF333 (Pyrus communis L.) pear rootstocks by culture-dependent technique; further, these isolates were also examined to explore the different characteristics predominantly plant growth promoting properties of endophytic isolates.

\section{Materials and methods}

\section{Detection and isolation of endophytic bacteria from in vitro cultures of peach and pear rootstocks}

In Plant Tissue Culture Laboratory of an agricultural company (Dikili Ciftlik in vitro Fidan A.S, Dikili-Izmir, Turkey), GF677 (P. amygdalus $\times P$. persica) peach rootstocks and OHF333 (P. communis L.) pear rootstocks were routinely cultured on MS medium (Murashige and Skoog 1962) having sucrose $(3 \%)$ as key ingredient and agar (0.6 \%), supplemented with benzylaminopurine $(2.22 \mu \mathrm{M})$, indole 3 butyric acid $(0.49 \mu \mathrm{M})$ and gibberellic acid $3(0.29 \mu \mathrm{M})$. Cultures were incubated under a photoperiod of $16 \mathrm{~h}$ at $24{ }^{\circ} \mathrm{C}$. It has been observed that in few batches of rootstock samples, instead of using several extensive surface sterilization methods prior to explant culturing, bacterial growth was repeatedly appearing within few days of cultivation. In contrast, no bacterial contamination was observed on control MS medium plates inoculated with the final wash solution of surface sterilization procedure which evidently proved the appropriateness of surface sterilization methods. Consequently, the bacteria frequently appeared on explant cultures were anticipated as endophytes and not the surface contaminates.
To further prove the occurrence of endophytic bacteria, explanation process was repeated using renowned surfacesterilized methodology for isolation of endophytes as described by Araújo et al. (2002). Rootstock samples were dipped in ethanol $(70 \%)$ for $1 \mathrm{~min}$, then in sodium hypochlorite $(2.5 \%)$ for $20 \mathrm{~min}$, subsequent washing with ethanol $(70 \%)$ for $30 \mathrm{~s}$ and finally rinsed three times with sterile distilled water. After surface disinfection, rootstocks were cut into pieces and were cultured on MS medium and incubated under same conditions. Plates were examined daily for bacterial colony development. Parallel to the samples again the final wash solution of surface sterilization procedure was also spread plated onto the MS medium plate which served as a control. Visible bacterial growth was isolated from the plates and aseptically streaked on nutrient agar plates and purified. Isolates were separated on the basis of their morphological characteristics, maintained in pure culture forms on the same medium and further processed for gram staining reactions as described by Hans Christian Gram (1884).

\section{Molecular identification of the isolates}

16S rRNA gene sequences were used for molecular identification of isolated bacterial strains. Amplification of the $16 \mathrm{~S}$ rRNA gene was performed with $27 \mathrm{~F}$ and $1492 \mathrm{R}$ universal primers. Genes were amplified and sequenced by a commercial company with an ABI 3100 Genetic Analyzer (RefGen, METU, Technopark-Ankara, Turkey). The obtained sequence data were edited and aligned, using Geneious bioinformatics software (version 8.1) and a contiguous consensus sequence was generated. Aligned contiguous consensus sequence of $16 \mathrm{~S}$ rRNA gene was used for homology search by the Basic Local Alignment Search Tool (BLAST) software (http://blast.ncbi.nlm.nih. gov) algorithm at National Center for Biotechnology Information (NCBI). The phylogenetic study of the $16 \mathrm{~S}$ rRNA gene sequences of the isolates was conducted with Geneious version 9 beta using neighbor-joining method. Data obtained after sequencing have been submitted in the NCBI GenBank database to attain accession numbers.

\section{Study of plant growth promoting properties}

\section{Quantification of indoleacetic acid (IAA)}

Quantitative detection of IAA was performed according to Acuña et al. (2011). Production of IAA was determined by colorimetric measurement at $530 \mathrm{~nm}$ using Salkowski's reagent. Single bacterial colonies of each endophytic isolate were inoculated and grown under shaking at $120 \mathrm{rpm}$ for 2 days at $30^{\circ} \mathrm{C}$ in LB broth supplemented with tryptophan $(1 \mathrm{mg} / \mathrm{ml})$ as IAA precursor. After incubation, the 
cells were centrifuged at $3000 \mathrm{rpm}$ for $10 \mathrm{~min}$ at $4{ }^{\circ} \mathrm{C}$ and $1 \mathrm{ml}$ of supernatant was mixed with $2 \mathrm{ml}$ of Salkowski's reagent $\left(150 \mathrm{ml}\right.$ of $95-98 \% \mathrm{H}_{2} \mathrm{SO}_{4}, 7.5 \mathrm{ml}$ of $0.5 \mathrm{M}$ $\mathrm{FeCl}_{3} \cdot 6 \mathrm{H}_{2} \mathrm{O}$, and $250 \mathrm{ml}$ distilled water) and incubated for $30 \mathrm{~min}$ at room temperature. The quantification of IAA was carried out using a standard curve with known concentrations of pure commercial IAA (Sigma-Aldrich, Co.). Uninoculated broth was used as negative controls and experiment is run in triplicate for each individual bacterium. Values are expressed in $\mu \mathrm{g} \mathrm{ml}^{-1}$.

\section{Determination of nitrogen fixation ability}

To determine the isolates' ability to fix atmospheric nitrogen, qualitative screening of growth was done on solid $\mathrm{N}$-free medium $\left(1 \mathrm{~g} \mathrm{~K} \mathrm{~K}_{2} \mathrm{HPO}_{4}, 5 \mathrm{mg} \mathrm{FeSO} \cdot 7 \mathrm{H}_{2} \mathrm{O}, 1 \mathrm{~g}\right.$ $\mathrm{CaCO}_{3}, 0.2 \mathrm{~g} \mathrm{NaCl}, 0.2 \mathrm{~g} \mathrm{MgSO}_{4} \cdot 7 \mathrm{H} 2 \mathrm{O}, 5 \mathrm{mg} \mathrm{NaMoO}$, $10 \mathrm{~g}$ glucose per litre, and $1.5 \%$ agar at $\mathrm{pH}$ 7.0). Visible bacterial colonies on the $\mathrm{N}$-free medium were used as the growth parameter and data were taken four and ten days post-inoculation (Ngamau et al. 2012).

\section{Phosphate solubilization}

The phosphate solubilizing activity of each of the isolates was determined by the method of Watanabe and Olsen (1965). Isolates were grown in $50 \mathrm{ml}$ of NBRIP (National Botanical Research Institute's phosphate) broth added with $\mathrm{Ca}_{3}\left(\mathrm{PO}_{4}\right)_{2}$ as insoluble forms of phosphate. Uninoculated NBRIP broth was used as control. The flasks were incubated on rotary shaker $(180 \mathrm{rpm})$ at $30{ }^{\circ} \mathrm{C}$ for 7 days, after incubation broth was centrifuged at 10,000 rpm for $20 \mathrm{~min}$. Supernatant was collected and autoclaved $\left(121^{\circ} \mathrm{C}\right.$ for $20 \mathrm{~min}$ ). Autoclaved samples were then filtered through $0.2 \mu \mathrm{m}$ filter and were used for the determination of the soluble phosphate released into the solution. Optical density was taken at $700 \mathrm{~nm}$ and quantity of solubilized phosphate was measured with the help of $\mathrm{KH}_{2} \mathrm{PO}_{4}$ standard curve ranging up to $1 \mu \mathrm{g} \mathrm{ml}^{-1}$. Uninoculated broth was used as negative controls and experiment is run in triplicate for each individual bacterium. Values are expressed in $\mu \mathrm{g} \mathrm{ml}{ }^{-1}$.

\section{Production of siderophore}

Siderophore production characteristic of isolates was determined using CAS blue agar medium comprising chrome azurol S (CAS) and indicator hexadecyltrimethylammonium bromide (HDTMA) (Schwyn and Neilands 1987). CAS agar was prepared by supplementing sterilized MM9 salt medium (850 ml) comprising piperazine-N, N0bis 2-ethanesulfonic acid (PIPES) (32.24 g), blue dye $(100 \mathrm{ml})$, filter sterilized $10 \%$ casaminoacid solution
$(30 \mathrm{ml})$ and $20 \%$ glucose solution $(10 \mathrm{ml})$. Isolates were inoculated on CAS agar plates and incubated at $28^{\circ} \mathrm{C}$ and results were recorded after $24 \mathrm{~h}$.

\section{Results and discussion}

Rootstocks of peach and pear plants were observed to comprise endophytic bacteria appeared during in vitro cultivation on MS medium. Surface sterilization method for isolation of endophytic bacteria was found adequate as control plate has not shown any growth. Therefore, bacterial colonies appeared on sample plates can be well thought-out as endophytic bacteria of peach and pear rootstocks. To the best of our knowledge, there is no report found on the isolation of endophytes from peach and pear in vitro rootstock cultures. Though, there are few studies reported for the isolation of endophytic microorganisms from micropropagated plants (Almeida et al. 2009; Dias et al. 2009).

A total of seven morphologically distinct isolates were found as endophytes and all seven isolates were identified and characterized. Plant roots may contain other microbial diversity, but most of the endophytic microorganisms are unculturable and need culture-independent techniques to detect and identify. In this work, culture-dependent technique is applied; therefore, only those isolates which have shown growth under in vitro conditions were studied. Thus, all morphologically distinct isolates found were selected for characterization/identification.

Five morphologically distinct bacterial colonies were purified from peach rootstock samples and two different colonies from pear rootstock samples, bacterial isolates were given unique isolate numbers (Table 1) and processed for Gram-staining reaction. Five isolates from peach samples and two isolates from pear were found as Gram-negative rod shaped bacteria, while one isolate of peach was observed as Gram-positive short rods which were further molecularly identified using $16 \mathrm{~S}$ rRNA gene partial sequencing. As $16 \mathrm{~S}$ rRNA gene sequence offers precise identification of bacteria up to subspecies level, it is well thought-out as the most suitable method (Jill and Clarridge 2004). Using 16S rRNA gene sequence data, endophytes of pear rootstocks were identified as Brevundimonas diminuta, Leifsonia shinshuensis, Sphingomonas parapaucimobilis, Brevundimonas vesicularis and Agrobacterium tumefaciens, while endophytic isolates of pear rootstocks were identified as Pseudoxanthomonas mexicana and Stenotrophomonas rhizophilia. NCBI GenBank Accession number of all isolates and the $99 \%$ similar isolate names are given in Table 1.

BLAST analysis of $16 \mathrm{~S}$ rRNA gene sequence data provided us fairly precise grouping of bacterial isolates up 
Table 1 16S rRNA gene sequence analysis

\begin{tabular}{|c|c|c|c|c|c|c|}
\hline $\begin{array}{l}\text { Isolate } \\
\text { number }\end{array}$ & $\begin{array}{l}\text { Endophytic bacterial } \\
\text { strain }\end{array}$ & $\begin{array}{l}\text { Source } \\
\text { plant }\end{array}$ & $\begin{array}{l}\text { Gram staining } \\
\text { reaction }\end{array}$ & $\begin{array}{l}\text { NCBI accession } \\
\text { number }\end{array}$ & NCBI database match & $\begin{array}{l}\text { Percentage } \\
\text { of identity }\end{array}$ \\
\hline EGE-B-1 & Brevundimonas diminuta & Peach & - & KP050788 & $\begin{array}{l}\text { Brevundimonas diminuta } \\
\quad \text { (EU430091) }\end{array}$ & 99 \\
\hline EGE-B-2A & Leifsonia shinshuensis & Peach & + & КР050789 & Leifsonia shinshuensis (KC345031) & 99 \\
\hline EGE-B-2B & $\begin{array}{l}\text { Sphingomonas } \\
\quad \text { parapaucimobilis }\end{array}$ & Peach & - & KP050790 & $\begin{array}{l}\text { Sphingomonas parapaucimobilis } \\
\quad \text { (AB680768) }\end{array}$ & 99 \\
\hline EGE-B-3 & $\begin{array}{l}\text { Pseudoxanthomonas } \\
\text { mexicana }\end{array}$ & Pear & - & KP050791 & $\begin{array}{l}\text { Pseudoxanthomonas mexicana } \\
\text { (KF358268) }\end{array}$ & 99 \\
\hline EGE-B-4 & $\begin{array}{l}\text { Brevundimonas } \\
\text { vesicularis }\end{array}$ & Peach & - & KP050792 & $\begin{array}{l}\text { Brevundimonas vesicularis } \\
\quad(\text { KR085853) }\end{array}$ & 99 \\
\hline EGE-B-5 & $\begin{array}{l}\text { Agrobacterium } \\
\text { tumefaciens }\end{array}$ & Peach & - & KP050793 & $\begin{array}{l}\text { Agrobacterium tumefaciens } \\
\text { (GQ181060) }\end{array}$ & 99 \\
\hline EGE-B-6 & $\begin{array}{l}\text { Stenotrophomonas } \\
\text { rhizophilia }\end{array}$ & Pear & - & KP050794 & $\begin{array}{l}\text { Stenotrophomonas rhizophilia } \\
\text { (KM096602) }\end{array}$ & 99 \\
\hline
\end{tabular}

Fig. 1 Phylogenetic analysis of 16S rRNA gene sequences of the bacterial isolates along with the reference sequences from NCBI. The analysis was conducted using neighborjoining method. The scale bar represents $0.03 \%$ substitutions of nucleotide

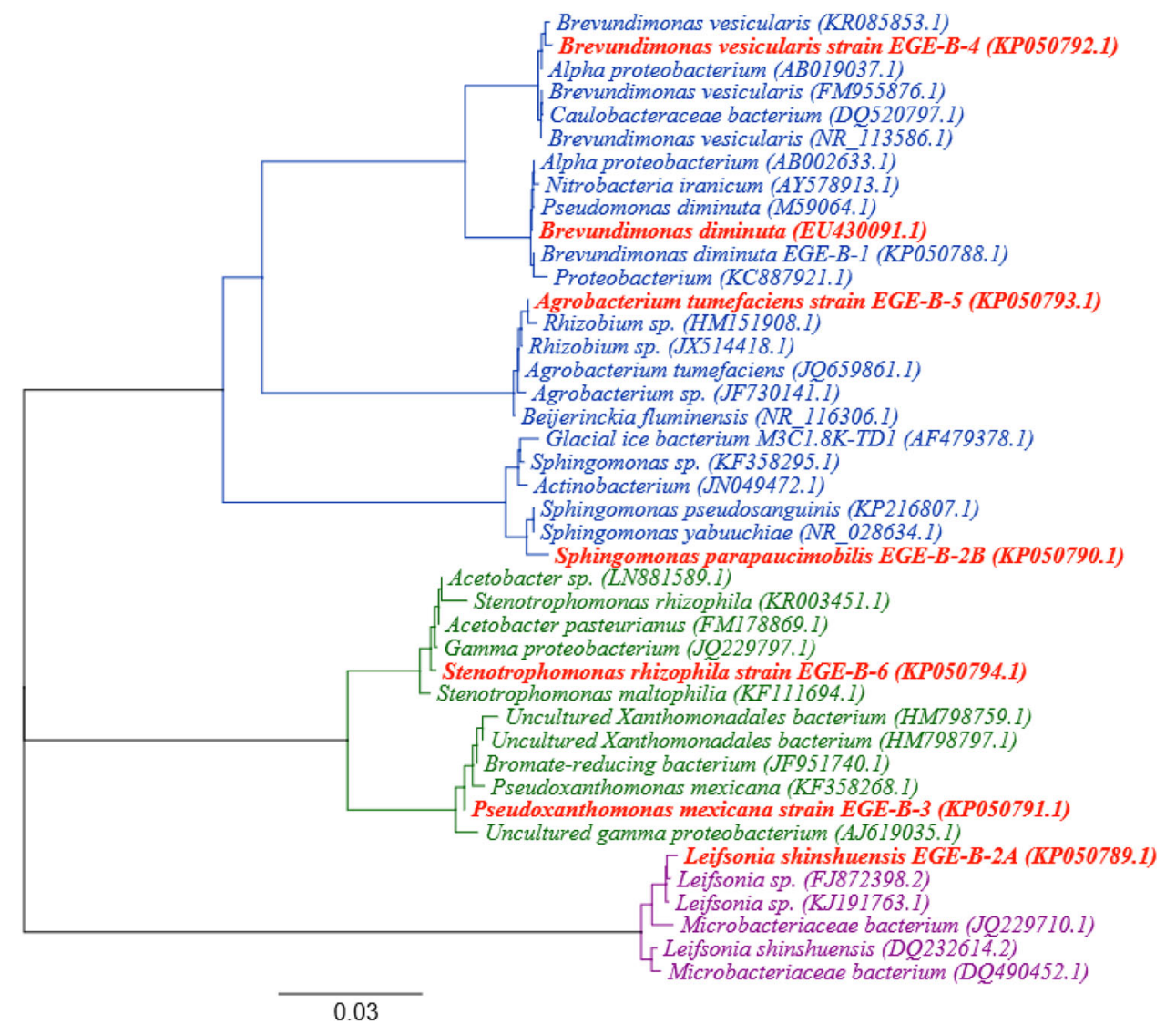

Brevundimonas vesicularis (KR085853.1) Alpha proteobacterium (AB002633.1) Nitrobacteria iranicum (AY578913.1) diminuta (MS9004.1)

dimonas diminuta EGE-B-1 (KP050788.1)

Proteobacterium (KC887921.1) Rhizobium sp. (HMI51908.1)

Rhizobium sp. (JX514418.1)

grobacterium tumefaciens (J0659861:1)

Igrobacterium SP. (JF730141.1)

Sphingomonas sp. (KF358295.1)

ctinobacterium (JN040472.1)

Sphingomonas pseudosanguinis (KP216807.1)

phingomonas yabuuchiae (NR_028634.1)

X11694.1)

- Pseudoranthomonas mexicana (KF358268. I)

Pseudoxanthomonas mexicana strain EGE-B-3 (KP

- Leifsonia shinshuensis EGE-B-2A (KP050789.1)

Leifsonia sp. (FJ872308.2)

Lejsonia sp. (KJ191763.1)

Leifsonia shinshuensis (DQ232614.2)

0.03

to the species level. The phylogenetic studies of $16 \mathrm{~S}$ rRNA gene sequence data of the our isolates plus the sequence data searched and retrieved from NCBI were performed with Geneious version 9 beta, applying Global Alignment type with free end gaps, $65 \%$ similarity Cost matrix, Tamura Nei genetic distance model and neighbor-joining tree build method (Fig. 1). Out of total seven isolated endophytic bacteria six strains including $B$. diminuta, $P$. mexicana, B. vesicularis, A. tumefaciens, S. rhizophilia and $S$. parapaucimobilis belong to phylum Proteobacteria while one strain L. shinshuensis belongs to phylum Actinobacteria. Different genus of Proteobacteria phylum including Brevundimonas, Sphingomonas and Pseudoxanthomonas was previously reported as endophytes of seeds of cotton and cucumber (Hallmann et al. 1998), rice plant (Mano and Morisaki 2008), endophytic bacterial community of 
soybean root (Zhang et al. 2011), and endophytes of hybrid maize (Liu et al. 2012). Actinobacteria were also reported as endophytes of rice roots (Sun et al. 2008) and Taxus rhizosphere (Hao et al. 2008). Another report detected the occurrence of Actinobacteria, Alphaproteobacteria and Betaproteobacteria as endophytes in pineapple microplants (Abreu-Tarazi et al. 2010). These results can also be correlated with the results of other studies, which revealed Proteobacteria as a predominant plant growth promoting, pathogen antagonist and beneficial endophyte group (Andreote et al. 2006, 2009; Dias et al. 2009). From this comparative analysis, it can be determined that these species of endophytes isolated from peach and pear have a wide range of host specificity.

Agrobacterium species are well-known soil born phytopathogens and cause various plant diseases like crown gall disease. On the other hand, Agrobacterium genus is found among repeatedly isolated endophytic bacterial strains of root nodules of a variety of wild and cultivated legumes (De Lajudie et al. 1999; Wang et al. 2006; Saïdi et al. 2013). The taxonomy and classification of Agrobacterium are, however, questioned, and there are many disagreements regarding the nomenclature of Agrobacterium species as well as the genus. Most species have been controversially reclassified as Rhizobium species (Farrand et al. 2003; Chihaoui et al. 2015). Strains of Agrobacterium genus may be either tumorigenic, rhizogenic or nonpathogenic depending on the type of plasmids they comprise (Chihaoui et al. 2015). Numerous reports have revealed that Agrobacterium strains recovered from the root nodules have not shown ability to re-nodulate the original hosts, thus reported as nonsymbiotic (Wang et al. 2006; Liu et al. 2010). Some are also lacking in pathogenicity features (De Lajudie et al. 1999). Recently, several studies have declared A. tumefaciens as true plant endophytes with growth promoting abilities and have confirmed its occurrence and coexistence along with different endophyte species in diverse range of host plants (Procópio et al. 2009; Liu et al. 2010; Luo et al. 2011; Chen et al. 2012; Rashid et al. 2012; Mufti et al. 2015; Pandya et al. 2015). In our present study, A. tumefaciens is identified among the endophytes of in vitro peach rootstocks cultures and it has shown the best plant growth promoting properties as compared to other endophytes isolated.

\section{Plant growth promoting properties}

Bacteria that inhabit the plant tissues as endophytes and which are not harmful for plant growth can display potentials to improve plant growth and can be advantageous for plant to augment symbiotic environment. The approaches by which the endophytes of peach and pear rootstocks could affect plant growth were examined by evaluating their capability for IAA production, nitrogen fixation, phosphate solubilization and siderophore production.

Endophytes can produce phytohormone IAA to promote plant growth (Mendes et al. 2007). IAA increases root size and distribution, resulting in a better nutrient uptake from the soil ( $\mathrm{Li}$ et al. 2008). All the endophytic strains were checked for their ability to produce IAA by quantitative method and it was recorded that all the seven isolates gave positive results. Result was interpreted by comparing samples with positive (pure indoleacetic acid) and negative (uninoculated broth) controls. Quantities of IAA detected after comparing with standard curve of pure IAA are shown in Table 2. When screened for IAA production, the highest production rate was observed by strain A. tumefaciens $\left(43.8 \pm 2.3 \mu \mathrm{g} \mathrm{ml}^{-1}\right)$ and lowest production was found in $B$. vesicularis $\left(9.6 \pm 2.9 \mu \mathrm{g} \mathrm{ml}^{-1}\right)$. Numerous past studies have shown that growth promoting bacteria of different species produce IAA (Piccoli et al. 2011; Rana et al. 2011; Jha et al. 2012; Mufti et al. 2015; Yaish et al. 2015). Plant roots contain tryptophan which can be consumed by endophytic bacteria as a precursor for IAA production; therefore, IAA quantification is considered as common trait among the characterization of plant-associated bacteria.

Endophytic isolates were also screened for their nitrogen fixing abilities by growing these bacteria on nitrogen-free medium. It is found that all these isolates have shown growth on nitrogen-free medium which suggested their ability to fix atmospheric nitrogen (Table 2). Nitrogenfixing ability of various endophytic bacteria was reported in many studies (Kuklinsky-Sobral et al. 2004; Sun et al. 2008; Li et al. 2010; Loaces et al. 2010; Pereira et al. 2012).

Phosphorus, is one of the plant growth limiting nutrients, which is added in the soil as fertilizer but usually becomes unavailable to the plant because of immobilization mechanism. However, bacteria living in plants play an important role in supplying phosphorus to plants. Endophytes are among those handy phosphate supplying bacteria (Wakelin et al. 2004). Phosphate solubilizing bacteria can change insoluble phosphates into soluble forms for plant through the process of acidification, chelation, exchange reactions, and production of organic acids (Chung et al. 2005). Endophytic bacteria in root zone are capable of increasing the availability of soil phosphorus to vegetation and improve plant growth (Duangpaenga et al. 2013). One of the most important phosphate solubilization mechanisms in plant-associated bacteria is the production of low-molecular weight organic acids which result in the acidification of the soil (Oteino et al. 2015). Isolates were screened quantitatively for their ability to solubilize phosphate. Results depicted that all isolates have ability to 
Table 2 Growth promoting properties of isolated endophytic bacterial strains

\begin{tabular}{|c|c|c|c|c|}
\hline \multirow[t]{2}{*}{ Endophytic bacterial strains } & \multicolumn{4}{|c|}{ Plant growth promoting properties } \\
\hline & $\begin{array}{l}\text { IAA Production } \\
\left(\mu \mathrm{g} \mathrm{ml}^{-1}\right)\end{array}$ & $\begin{array}{l}\text { Phosphate solubilization } \\
\left(\mu \mathrm{g} \mathrm{ml}^{-1}\right)\end{array}$ & $\begin{array}{l}\text { Nitrogen } \\
\text { fixation }\end{array}$ & $\begin{array}{l}\text { Siderophore } \\
\text { production }\end{array}$ \\
\hline Brevundimonas diminuta & $32.8 \pm 1.8$ & $6.8 \pm 1.1$ & + & - \\
\hline Leifsonia shinshuensis & $24.9 \pm 1.7$ & $20.4 \pm 0.8$ & + & - \\
\hline Sphingomonas parapaucimobilis & $16.7 \pm 1.2$ & $9.8 \pm 0.8$ & + & - \\
\hline Pseudoxanthomonas mexicana & $28.0 \pm 0.9$ & $15.8 \pm 0.3$ & + & - \\
\hline Brevundimonas vesicularis & $9.6 \pm 2.9$ & $8.4 \pm 1.3$ & + & - \\
\hline Agrobacterium tumefaciens & $43.8 \pm 2.3$ & $26.0 \pm 1.1$ & + & + \\
\hline Stenotrophomonas rhizophilia & $10.8 \pm 1.3$ & $9.6 \pm 1.6$ & + & + \\
\hline
\end{tabular}

Average values of three independent experiments for each isolate in triplicate \pm standard deviation

solubilize insoluble phosphate by producing phosphatase enzyme. Quantitatively phosphate solubilizing abilities of these bacteria range between $6.8 \pm 1.1 \mu \mathrm{g} \mathrm{ml}^{-1}$ by $B$. diminuta to $26.0 \pm 1.1 \mu \mathrm{g} \mathrm{ml}^{-1}$ by $A$. tumefaciens (Table 2). Previously, phosphate solubilizing abilities of endophytes have also been reported in several varieties of crops (Palaniappan et al. 2010). Likewise, Mufti et al. 2015 recently reported phosphate solubilizing capabilities of different endophytic isolates, including A. tumefaciens predominant among other endophytes with maximum phosphate solubilization activity.

The production of siderophores by endophytes is advantageous for plants, as it is one of the mechanisms to outcompete phytopathogens by inhibiting their growth within the plants (Sharma and Johri 2003). Siderophores produced by bacteria may promote the plant growth directly, by providing iron to plant, as iron accessibility to plants is usually low; therefore, organic chelators produced by bacteria will help in iron absorption or benefit plants indirectly, by obstructing the availability of iron to pathogens, thus restraining pathogen growth (Szilagyi-Zecchin et al. 2014).

Siderophore production properties were detected by chrome azurol S (CAS) agar. Out of seven endophytes, all isolates have shown growth on CAS agar but only $A$. tumefaciens and S. rhizophilia have shown positive results for siderophore production in the form of orange halo around the colonies (Table 2). Development of yellow to orange halo around the growth indicates iron chelation commenced by produced siderophores. Isolates showing no color change around growth were declared as negative for siderophore production property. Siderophore has the ability to take away the iron from the dye complex resulting in the color change to yellowish orange (Schwyn and Neilands 1987). These siderophores producing endophytes reduce the accessibility of iron for iron requiring phytopathogens by sequestrating available iron. Hence, they indirectly improve the plant growth (Alexander and
Zeeberi 1991). Endophytic A. tumefaciens strain was recognized for its ability to produce siderophores in a past report by Luo et al. (2011) using CAS analytical method. There are many reports affirming the capacity of Stenotrophomonas species to produce different forms of siderophores with the help of universally applicable CAS assay. Chhibber et al. (2008) described ornibactin type siderophore production by Stenotrophomonas maltophilia and in another study Ryan et al. (2009) revealed its potential to produce compound enterobactin which is catechol type siderophore.

Current outcomes are consistent with the likelihood that individual biological roles can be mutually performed by different bacterial species of similar ecological environment. For example, IAA production, phosphate solubilization and nitrogen fixation properties were detected in all seven isolates, which were belonged to distinct species. Additionally, high score for IAA production also matches with phosphate solubilization. For example, the highest production of IAA and phosphate solubilization both were observed in A. tumefaciens. However, plant growth enhancement is an outcome of pooled potentials encompassed by multiple types of bacteria associated with these plants.

\section{Conclusion}

In the end of our study, we do not claim the isolation and detection of every endophytic strain in peach and pear rootstocks. However, we concluded that some of the bacterial strains isolated from peach and pear have the ability to produce the growth regulator IAA, to fix nitrogen and to solubilize phosphate. Two of the strains also have the ability to produce siderophore. Five out of seven isolates belong to same phylum, thus we can relate such similarities to the endophytic ecology of bacterial species, and also to plant metabolism and nutrient accessibility. Further studies 
are required to reveal the potential of these endophytes as biofertilizers. Moreover, greenhouse and field investigations are recommended for confirmation of this potentiality. Antimicrobial susceptibility profiles of these endophytes could suggest the best options for their control in in vitro plant tissue culture.

Acknowledgments The authors would like to thank Plant Tissue Culture Laboratory of Dikili Ciftlik in vitro Fidan A. S, Dikili-Izmir, Turkey, for kindly providing us endophytes comprising rootstock samples.

\section{Compliance with ethical standards}

Conflict of interest The authors declare that they have no conflict of interest.

Open Access This article is distributed under the terms of the Creative Commons Attribution 4.0 International License (http:// creativecommons.org/licenses/by/4.0/), which permits unrestricted use, distribution, and reproduction in any medium, provided you give appropriate credit to the original author(s) and the source, provide a link to the Creative Commons license, and indicate if changes were made.

\section{References}

Abreu-Tarazi MF, Navarrete AA, Andreote FD, Almeida CV, Tsai SM, Almeida M (2010) Endophytic bacteria in long-term in vitro cultivated "axenic" pineapple microplants revealed by PCRDGGE. World J Microbiol Biotechnol 26:555-560

Acuña JJ, Jorquera MA, Martínez OA, Menezes-Blackburn D, Fernández MT, Marschner P, Greiner R, Mora ML (2011) Indole acetic acid and phytase activity produced by rhizosphere bacilli as affected by $\mathrm{pH}$ and metals. J Soil Sci Plant Nutr 11:1-12

Alexander BD, Zeeberi DA (1991) Use of chromazurol S to evaluate siderophore production by rhizosphere bacteria. Biol Fertil Soils 2:39-54

Almeida CV, Andreote F, Yara R, Tanaka FAO, Azevedo JL, Almeida M (2009) Bacteriosomes in axenic plants: endophytes as stable endosymbionts. World $\mathrm{J}$ Microbiol Biotechnol 25(10): 1757-1764

Andreote FD, Lacava PT, Gai CS, Araujo WL, Maccheroni W, van Overbeek LS, van Elsas JD, Azevedo JL (2006) Model plants for studying the interaction between Methylobacterium mesophilicum and Xylella fastidiosa. Can J Microbiol 52:419-426

Andreote FD, Rossetto PB, Mendes R, Avila LA, Labate CA, Pizzirani- Kleiner AA, Azevedo JL, Araújo WL (2009) Bacterial community in the rhizosphere and rhizoplane of wild type and transgenic eucalyptus. World J Microbiol Biotechnol. doi:10. 1007/s11274-009-9990-9

Araújo WL, Marcon J, Maccheroni W Jr, Elsas JDV, van Vuurde JWL, Azevedo JL (2002) Diversity of endophytic bacterial populations and their interaction with Xylella fastidiosa in citrus plants. Appl Environ Microbiol 68:4906-4914

Chen L, Luo S, Chen J, Wan Y, Liu C, Liu Y, Pang X, Lai C, Zeng G (2012) Diversity of endophytic bacterial populations associated with Cd-hyperaccumulator plant Solanum nigrum L. grown in mine tailings. Appl Soil Ecol 62:24-30

Chhibber S, Gupta A, Sharan R, Gautam V, Ray P (2008) Putative virulence characteristics of Stenotrophomonas maltophilia: a study on clinical isolates. World J Microbiol Biotechnol 24:2819-2825

Chihaoui S, Trabelsi D, Jdey A, Mhadhbi H, Mhamdi R (2015) Agrobacterium sp. $10 \mathrm{C} 2$ affects richness and structure of rhizosphere bacterial communities and enhances nodulation and growth. Arch Microbiol 197:805-813

Chung H, Park M, Madhaiyan M, Seshadri S, Song J, Cho H, Sa T (2005) Isolation and characterization of phosphate solubilizing bacteria from the rhizosphere of crop plants of Korea. Soil Biol Biochem 37:1970-1974

De Lajudie P et al (1999) Agrobacterium bv. 1 strains isolated from nodules of tropical legumes. Syst Appl Microbiol 22:119-132

Dias ACF, Costa FEC, Andreote FD, Lacava PT, Teixeira MA, Assumpção LC, Araujo WL, Azevedo JL, Melo IS (2009) Isolation of micropropagated strawberry endophytic bacteria and assessment of their potential for plant growth promotion. World J Microbiol Biotechnol 25:189-195

Duangpaenga A, Phetcharata P, Chanthaphoa S, Okuda N (2013) Screening of endophyte bacteria for phosphate solubilization from organic rice. In: Proceeding-Science and Engineering, pp 61-66

Farrand SK, van Berkum PV, Oger P (2003) Agrobacterium is a definable genus of the family Rhizobiaceae. Int J Syst Evol Microbiol 53:1681-1687

George EF, Hall MA, De-Klerk GJ (2008) Plant propagation by tissue culture, 3rd edn. Springer, Dordrecht, pp 1-28

Hallmann J, Quadt-Hallmann Bana RR, Kloepper JW (1998) Interactions between Meloidogyne incognita and endophytic bacteria in cotton and cucumber. Soil Biol Biochem 30:925-937

Hao DC, Ge GB, Yang L (2008) Bacterial diversity of Taxus rhizosphere: culture-independent and culture-dependent approaches. FEMS Microbiol Lett 284:204-212

Jha B, Gontia I, Hartmann A (2012) The roots of the halophyte Salicornia brachiata are a source of new halotolerant diazotrophic bacteria with plant growth-promoting potential. Plant Soil 356:265-277

Jill E, Clarridge III (2004) Impact of 16S rRNA gene sequence analysis for identification of bacteria on clinical microbiology and infectious diseases. Clin Microbiol Rev 17:840-862

Khalifa AYZ, Alsyeeh AM, Almalki MA, Farag A (2015) Characterization of the plant growth promoting bacterium, Enterobacter cloacae MSR1, isolated from roots of non-nodulating Medicago sativa. Saudi J Biol Sci. doi:10.1016/j.sjbs.2015.06.008

Kuklinsky-Sobral J, Araújo WL, Mendes R, Geraldi IO, PizziraniKleiner AL, Azevedo JL (2004) Isolation and characterization of soybean-associated bacteria and their potential for plant growth promotion. Environ Microbiol 12:1244-1251

Kumala S, Siswanto EB (2007) Isolation and screening of endophytic microbes from Morinda citrifolia and their ability to produce anti-microbial substances. Microbiol Indonesia 1:145-148

Li JH, Wang ET, Chen WF, Chen WX (2008) Genetic diversity and potential for promotion of plant growth detected in nodule endophytic bacteria of soybean grown in Heilongjiang province of China. Soil Biol Biochem 40:238-246

Li CH, Zhao MW, Tang CM, Li SP (2010) Population dynamics and identification of endophytic bacteria antagonistic toward plantpathogenic fungi in cotton root. Microb Ecol 59:344-356

Liu J, Wang ET, Ren DW, Chen WX (2010) Mixture of endophytic Agrobacterium and Sinorhizobium meliloti strains could induce nonspecific nodulation on some woody legumes. Arch Microbiol 192:229-234

Liu Y, Zuo S, Xu L, Zou Y, Song W (2012) Study on diversity of endophytic bacterial communities in seeds of hybrid maize and their parental lines. Arch Microbiol. doi:10.1007/s00203-0120836-8 
Loaces I, Ferrando L, Scavino AF (2010) Dynamics, diversity and function of endophytic siderophore-producing bacteria in rice. Microb Ecol 61:606-618

Luo S, Chen L, Chen J, Xiao X, Xu T, Wan Y, Rao C, Liu C, Liu Y, Lai C, Zeng G (2011) Analysis and characterization of cultivable heavy metal-resistant bacterial endophytes isolated from Cdhyperaccumulator Solanum nigrum L. and their potential use for phytoremediation. Chemosphere 85:1130-1138

Mano H, Morisaki H (2008) Endophytic bacteria in the rice plant. Microbes Environ 23(2):109-117

Mendes R, Pizzirani-Kleiner AA, Araujo WL, Raaijmakers JM (2007) Diversity of cultivated endophytic bacteria from sugarcane: genetic and biochemical characterization of Burkholderia cepacia complex isolates. Appl Environ Microbiol 73:7259-7267

Moraes RM, Melo IS, Sumyanto J, Chandra S, Joshi V (2012) Bacterial community associated with autotrophic and heterotrophic cultures of medicinal plant Smallanthus sonchifolius (Yacon). Am J Plant Sci 3:1382-1389

Mufti R, Amna Rafique M, Haq F, Hussain MF, Munis Masood S, Mumtaz AS, Chaudhary HJ (2015) Genetic diversity and metal resistance assessment of endophytes isolated from Oxalis corniculata. Soil Environ 34:89-99

Murashige T, Skoog F (1962) A revised medium for rapid growth and bio assays with tobacco tissue cultures. Physiol Plant $15: 473-497$

Muzzamal H, Sarwar R, Sajid I, Hasnain S (2011) Isolation, identification and screening of endophytic bacteria antagonistic to biofilm formers. Pak J Zool 44:249-257

Nair DN, Padmavathy S (2014) Impact of endophytic microorganisms on plants, environment and humans. Sci World J. doi:10.1155/ 2014/250693

Ngamau CN, Matiru VN, Tani A, Muthuri CW (2012) Isolation and identification of endophytic bacteria of bananas (Musa spp.) in Kenya and their potential as biofertilizers for sustainable banana production. Afr J Microbiol Res 6:6414-6422

Oteino N, Lally RD, Kiwanuka S, Lloyd A, Ryan D, Germaine KJ, Dowling DN (2015) Plant growth promotion induced by phosphate solubilizing endophytic Pseudomonas isolates. Front Microbiol. doi:10.3389/fmicb.2015.00745

Palaniappan P, Chauhan PS, Saravanan VS, Anandham R et al (2010) Isolation and characterization of plant growth promoting endophytic bacterial isolates from root nodule of Lespedeza sp. Biol Fert Soils 46:807-816

Pandya M, Rajput M, Rajkumar S (2015) Exploring plant growth promoting potential of non rhizobial root nodules endophytes of Vigna radiata. Microbiology 84:80-89

Pereira GVM, Magalhães KT, Lorenzetii ER, Souza TP, Schwan RF (2012) A multiphasic approach for the identification of endophytic bacterial in strawberry fruit and their potential for plant growth promotion. Microb Ecol 63:405-417

Piccoli P, Travaglia C, Cohen A, Sosa L, Cornejo P, Masuelli R, Bottini R (2011) An endophytic bacterium isolated from roots of the halophyte Prosopis strombulifera produces ABA, IAA, gibberellins A1 and A3 and jasmonic acid in chemically-defined culture medium. Plant Growth Regul 64:207-210

Procópio WL, Araújo W, Maccheroni J, Azevedo JL (2009) Characterization of an endophytic bacterial community associated with Eucalyptus spp R.E.L. Genet Mol Res 8:1408-1422

Rana A, Saharan B, Joshi M, Prasanna R, Kumar K, Nain L (2011) Identification of multi-trait PGPR isolates and evaluating their potential as inoculants for wheat. Ann Microbiol 61:893-900

Rashid S, Charles TC, Glick BR (2012) Isolation and characterization of new plant growth-promoting bacterial endophytes. Appl Soil Ecol 61:217-224

Ryan RP, Monchy S, Cardinale M, Taghavi S, Crossman L, Avison MB, Berg G, van der Lelie D, Dow JM (2009) The versatility and adaptation of bacteria from the genus Stenotrophomonas. Nat Rev Microbiol 7:514-525

Saïdi S, Chebil S, Gtari M, Mhamdi R (2013) Characterization of root-nodule bacteria isolated from Vicia faba and selection of plant growth promoting isolates. World J Microbiol Biotechnol 29:1099-1106

Schwyn B, Neilands JB (1987) Universal chemical assay for the detection and determination of siderophores. Anal Biochem 160(1):47-56

Sharma A, Johri BN (2003) Growth promoting influence of siderophore-producing Pseudomonas strains GRP3A and PRS9 in maize (Zea mays L.) under iron limiting conditions. Microbiol Res 158:243-248

Sun L, Qiu F, Zhang X, Dai X, Dong X, Song W (2008) Endophytic bacterial diversity in rice (Oryza sativa L.) roots estimated by 16S rDNA sequence analysis. Microb Ecol 55:415-424

Szilagyi-Zecchin VJ, Ikeda AC, Hungria M, Adamoski D, KavaCordeiro V, Glienke C, Galli-Terasawa LV (2014) Identification and characterization of endophytic bacteria from corn (Zea mays L.) roots with biotechnological potential in agriculture. AMB Express 4:26

Wakelin S, Warren R, Harvey P, Ryder M (2004) Phosphate solubilization by Penicillium spp. closely associated with wheat roots. Biol Fertil Soils 40:36-43

Wang LL, Wang ET, Liu J, Li Y, Chen WX (2006) Endophytic occupation of root nodules and roots of Melilotus dentatus by Agrobacterium tumefaciens. Microb Ecol 52:436-443

Watanabe FS, Olsen SR (1965) Test of an ascorbic acid method for determining phosphorus in water and $\mathrm{NaHCO}_{3}$ extracts from soil. Soil Sci Soc Am Proc 29:677-678

Yaish MW, Antony I, Glick BR (2015) Isolation and characterization of endophytic plant growth promoting bacteria from date palm tree (Phoenix dactylifera L.) and their potential role in salinity tolerance. Antonie Van Leeuwenhoek 107:1519-1532

Zhang YZ, Wang ET, Li M, Li QQ, Zhang YM, Zhao SJ, Jia XL, Zhang LH, Chen WF, Chen WX (2011) Effects of rhizobial inoculation, cropping systems and growth stages on endophytic bacterial community of soybean roots. Plant Soil 347:147-161 